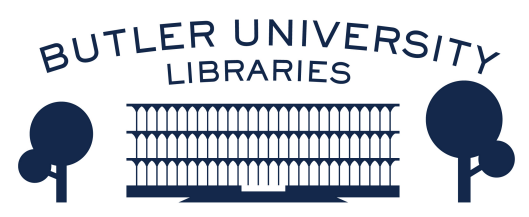

Journal of Hindu-Christian Studies

Volume 17

Article 9

January 2004

\title{
A Bibliographic Essay on Hindu and Christian Dalit Religiosity
}

Mathew N. Schmalz

Follow this and additional works at: https://digitalcommons.butler.edu/jhcs

Part of the Religion Commons

\section{Recommended Citation}

Schmalz, Mathew N. (2004) "A Bibliographic Essay on Hindu and Christian Dalit Religiosity," Journal of Hindu-Christian Studies: Vol. 17, Article 9.

Available at: https://doi.org/10.7825/2164-6279.1318

The Journal of Hindu-Christian Studies is a publication of the Society for Hindu-Christian Studies. The digital version is made available by Digital Commons @ Butler University. For questions about the Journal or the Society, please contact cbauman@butler.edu. For more information about Digital Commons @ Butler University, please contact digitalscholarship@butler.edu. 


\title{
A Bibliographic Essay on Hindu and Christian Dalit Religiosity
}

\author{
Mathew N. Schmalz \\ College of the Holy Cross
}

\begin{abstract}
IN his now classic novel Untouchable, Mulk Raj Anand portrays the life of a sweeper named Bakha. ${ }^{1}$ Bakha works cleaning latrines at the Cantonment, imitates the British "tommies" in his attire, and negotiates the differing spaces in which his Untouchability is defined. After an incident during which Bakha inadvertently touches a caste Hindu in the street, Bakha wanders through town. During his wanderings; he first meets a Christian missionary who speaks almost incomprehensibly about Jesus. Bakha then listens to a speech by Mahatma Gandhi and while he finds the Mahatma's vision compelling, his mind turns to reflecting upon how flush toilets might be the real answer to his plight. As Anand portrays him, Bakha the sweeper is neither Hindu nor can he somehow become a Christian, for as an Untouchable he remains trapped in a wholly other spatial domain. In his introduction to Untouchable, E. M. Forrester observes that only a Kshatriya like Anand could write about Untouchability, since an Untouchable would be too overcome with rage, while a foreigner could not begin to understand the depths of Untouchable degradation. But more often than not, Bakha emerges as à distant figure
\end{abstract}

who is portrayed often in terms of stereotypical images of the Untouchable as dark and physically powerful. Perhaps for Anand as well, Untouchable experience was a cipher that did not easily lend itself to understanding.

Within the academic study of South Asia, no issue remains more contested than the issue of caste and Untouchability. Most recently, of course, the Western emphasis upon hierarchy in the study of India has been brought under withering academic fire. For example, in a searing review essay in the American Ethnologist, Arjun Appadurai takes to task a whole corpus of scholarship that draws its inspiration from Louis Dumont's homo hierarchicus. ${ }^{2}$ Appadurai argues that instead of representing a new approach to the study of South Asia, Dumont's work and its derivatives represent instead a swan song for Orientalist approaches in which India civilization is understood to be the ultimate counter-type to the West. Of course, there is no question that much of Western scholarship on India uses caste as an essentialising marker of Indianness in ways that are much more closely related to Western problematics than to Indian ones. Nonetheless, to ignore the

\footnotetext{
Mathew N. Schmalz received his Ph.D. from the University of Chicago in History of Religions. He is presently an Edward Bennett Williams Fellow in the Department of Religious Studies at the College of the Holy Cross where he has also served as Director of Asian Studies. He has published in the areas of Christianity in North India, American Catholicism, and Modern Religious Movements.
} 
existence of caste and most particularly the experience of Untouchables themselves is to overcompensate for the undeniable fetishization of hierarchy in much Western scholarship on South Asia. In this bibliographic essay, I wish to overview and place into dialogue a range of works on Untouchability that take the religious vision of Untouchables seriously. As the historian John Webster has remarked, caste is generally independent of religiosity, for both Hindu and Christian members of Untouchable castes are often treated as equally inferior. ${ }^{3}$ It is within this context that the term "Dalit," meaning "oppressed" or "broken," takes its form. What unifies the wide range of work on Dalit experience and religiosity is an acknowledgement of caste as a construct that is not bound to a single religious community or institution.

\section{General Works on Untouchability}

In his study, The Pastor to Dalits, John Webster sympathetically presents interactions between Protestant pastors and Dalit parishioners as a means for fostering renewed pastoral approaches to ministry. ${ }^{4}$ By contrast, James Freeman's account of the life of the Indian Untouchable Muli cannot resist judging Untouchable life and particularly the machinations of Muli - from whom Freeman goes to great lengths to distance himself.5 What both these works indicate is that underlying many academic treatments of Dalit life there is an alternation between judgment and solidarity. Oscillation between these two poles of perspective has also shaped the range of historical works on Untouchability as a whole.

\section{Early Works}

The first extensive ethnographic treatment of Untouchables and Untouchable life can be found in Abbé Dubois's, Hindu Manners, Customs and Ceremonies. ${ }^{6}$ Dubois was a missionary who lived in the Madras Presidency and the Deccan in the first part of the $19^{\text {th }}$ century and his ethnographic observations were later published in both French and English. Dubois focuses his remarks on the restrictions placed upon the Tamil Parayer (Paraiyer) caste, from whose name he suggests the European word "pariah" is derived. Dubois does not delve into any detail with regard to Parayer practices and instead puts forth a rather aggressive argument that Parayer and other Untouchable castes suffer conditions far worse than slaves in the Western world. Dubois serially diagrams the various restrictions attendant upon Parayer members and moves to relate these strictures to those faced by other Untouchable castes of cobblers and leatherworkers. Dubois surmises that the "degraded classes". must have originally been composed of "all disreputable individuals of different classes of society, who, on account of various offenses, had forfeited their right to associate with respectable men." 7 Once separated from society, these "disreputable individuals" formed a class apart. In Dubois's view, these original character traits continue in the Untouchable castes he observed who, since they have no stake in society, give themselves over to numerous "vices." 8

Dubois observes that Untouchables seem resigned to their state, and this is a point made in another early and significant treatment of Untouchable life, The Chamars by George Briggs. Briggs was also a missionary, and although this perspective most certainly colors his presentation, his ethnographic observations of the Chamar caste of leatherworkers in Uttar Pradesh are still unmatched in their breadth. Like Dubois, Briggs emphasizes the restrictions applied to Chamar life such as denial of access to communal water sources and confinement to colonies outside of villages. ${ }^{9}$ But Briggs also describes in great detail elements of what could be called Chamar religious life. For example, Briggs talks about the significance of the exorcist (ojha) who would divine various afflictions and 
who would also be one of the principle mediators between Chamras and the higher castes for whom he would often perform services. Briggs also introduces the significant figures in the Chamar religious imagination, such as the niguni poets Raidas, Shivnarayan and Kabir. But in even stronger terms than Dubois, Briggs portrays Untouchables as gullible, superstitious, and intemperate.

\section{Hierarchy, Politics and Conversion}

More recent works on Untouchability have moved away from the judgmental posture assumed by Dubois and Briggs. Bernard Cohen conducted a study of a Chamar community in Eastern Uttar Pradesh in the 1950 s that discussed how Untouchables negotiated the hierarchical standards of the society surrounding them - challenging them and sometimes appropriating them. ${ }^{10}$ In a controversial work, Michael Moffat discussed how a South Indian community of Untouchables replicated hierarchical distinctions. ${ }^{11}$ Moffat argued that his data suggested an underlying consensus surrounding hierarchy in Indian society. Robert Deliège has vigorously contested Moffat's treatment of Untouchability by emphasizing the diversity and complexity of Untouchable life. ${ }^{12}$ Such a view would also be taken by Andre Beteille who places his discussion of Untouchable life within his argument against the current reservation system which sees little or no distinction between Scheduled and Backward Castes. ${ }^{13}$ Within Beteille's work in particular, there is an implicit concern with how scholarship on Untouchability can advance Dalit political agenda. Such a concern also animates historical treatments of Dalit Christian movements. Works by missionaries such as Bishop J. W. Pickett and John C. B. Webster situate their reflections within a concern for how Christianity has or has not, and potentially can, aid the development of broader understandings of Dalit solidarity. ${ }^{14}$ As scholarship on Untouchability has grown and developed itself, approaches have thus moved from stances of hierarchical judgment to a scholarly commitment to advancing Dalit concerns.

\section{Dalit Hindu Religiosity}

The relationship between Untouchables and Hinduism is complex, especially given the quite obvious fact that Hinduism itself is a bitterly contested construct. There are a variety of historical treatments of Untouchable religiosity, most notably Saurabh Dube's discussion of Ghasidas and the Satnamis in Untouchable Pasts. ${ }^{15}$ But ethnography remains the method that is often most sensitive not only to the permutations of Untouchable life but also to how scholarship discursively constructs Untouchability itself.

\section{Parasuram and the Ramnamis}

One of the most sensitive and ethnographically rich discussions of Untouchable life can be found in Ramdas Lamb's Rapt in the Name: The Ramnamis, Ramnam and Untouchable Religion in Central India. ${ }^{16}$ An American academic in addition to being Ramnami himself, Lamb is able to-strike an effective balance between his insider and outsider status. The Ramnamis were founded in the $19^{\text {th }}$ century by a Chamar named Parasuram in Charasurua in the Chhattisgarh region. When a young man, Parasuram was afflicted by a disease many thought to be leprosy. Parasuram's home was visited by a holyman named Ramdev who instructed him that all his desires would be fulfilled by reading the Ramcharitmanas and repeating the Ramnam. When he awoke in the morning, Parasuram saw words "Ram Ram" imprinted on his chest. ${ }^{17}$

Parasuram began to speak of his experience and he attracted followers who would join him to read the Ramcharitmanas, sing bhajans and repeat the Ramnam. At the time of Parasuram's death in 1920 the Ramnam samaj had àpproximately 20,000 members and was continuing to grow. 
Because the Ramnamis were largely from Untouchable castes, they were often bitterly resented by caste Hindus for their repetition of the divine name. But in the years since Parasuram's death, the Ramnamis have developed their own distinctive religious life. In addition to their devotion to the Ramnam and the Manas, the Ramnamis practice the tattooing of the name Ram over their bodies in a practice called "ankit." Additionally, they wear shawls marked by the Ramnam and often sport crowns with peacock feathers. When Lamb presents biographical sketches of six Ramnamis, what emerges is a richly layered notion of embodiment in which these Untouchables represent and rework through their bodies a new system of values. What Lamb emphasizes is a sophisticated resistance to caste Hindu understandings of purity, pollution, and religious exclusivity. While Lamb does not explicitly treat understandings of embodiment in relation to the Ramnamis, perhaps his work's most suggestive contribution is precisely to understanding the multiple resonances of embodiment. Most clearly, the Ramnamis revalue the status and signifying potential of the Untouchable body - a body that is now inscribed by the divine Name. But what is also intriguing is how Ramdas Lamb implicitly sets his own embodiment as a Ramnami sadhu as a hermeneutical bridge between his life as scholar and the religious community he seeks to study.

\section{Pragmatism and Tactics}

One of the most sophisticated theoretical treatments of Dalit religiosity is The Untouchable as Himself by Ravindra Khare. Khare focuses upon the religious vision of the Chamars of Lucknow. ${ }^{18}$ Combining ethnographic description with theoretical reflection, Khare diagrams what could be called the pragmatics of Untouchable asceticism. For the Chamars of Lucknow, asceticism is characterized by an ecletic and pragmatic combination of "Hindu monism (advaitu), Buddhist 'vacuity,' the later
Hindu notions of 'public service' (jana seva) and the Indian reformers notion of 'humanism' (manava dharma)."19 In describing and subdividing Untouchable asceticism into "worldly" and "protesting" modes, Khare is able to diagram a complex series of moves by which Chamars of Lucknows effectively diversify and broaden the social field to create new spaces for selfexpression and agency. In his conclusion Khare moves to engage post-modern theory, particularly the work of Jacques Derrida. Khare draws upon Derrida's understanding of "difference" to describe how Chamars transform the ground of caste Hindu discourse through "differing" and "deferring" devices of speech, writing and political action. ${ }^{20}$

The post-modern turn in the study of Untouchability has been subject to withering academic attack. In a searing essay writing in response to the scholarly approach taken by some members of the subaltern collective, Rosalind O'Hanlon and Michael Westbrook argue that post-modern approaches are self-referentially. incoherent. $^{21}$ More to the point, $\mathrm{O}^{\prime}$ Hanlon and Westbrook maintain that Derridan plays of "difference" do nothing to advance solidarity or incisive political critique, particularly within the global context of the subordinating and homogenizing forces of late capitalism. Khare's work is not postmodern in the strong sense, since he does rely upon sociological method and analysis as much as upon post-modern theorizing about "alterity." In many ways, however, Khare's work could be understood to respond to the charges leveled against postmodern theorists by Marxist historians. Khare seeks to probe the Chamar's implicit understanding of "homo justus," in opposition to the Dumontian construct of "homo hierarchicus" as the animating feature of Indian civilization. But as Khare attempts to schematize competing Indian and Western conceptions of equality and "individuation," it is clear from his ethnographic fieldwork that Chamar 
pragmatism defies characterization into discrete thematic or analytical frames. Gayatri Chakravarty Spivak argues that subaltern history is always subject to appropriation or "cathexsis" of the elite. ${ }^{22}$ While Untouchables can never speak "as themselves" within the pages of an academic work, descriptive strategies that model their shifting interventions and modes of resistance at the very least prevent the appropriation of Untouchable experience for political or academic meta-narratives that are not their own.

\section{Dalit Christian Religiosity}

Neither Ramdas Lamb nor Ravindra Khare use the word "Dalit" to describe the Untouchables about whom they write. For the Ramnamis and the Chamars of Lucknow the term evidently carries unwelcome connotations relating to the contested domain of Indian political discourse. Of course, Dalit is the preferred term for those who identify themselves with Untouchable or Scheduled caste political parties such as the Bahujan Samaj. But increasingly the term Dalit is used within Indian Christian discourse that presents Christianity as the most powerful path of liberation from the strictures of caste.

\section{Dalit Protestant Theology}

In recent decades Indian Protestantism has made the most aggressive effort to develop what is envisioned as an indigenously Indian form of liberation theology. Sponsored by Indian Christian seminaries, a variety of edited volumes have been published that explore the theological and political implications of Dalit Christian experience. and witness. James Massey, the head of the Delhi-based Indian Society for the Promotion of Christian Knowledge, has been at the forefront of developing a Dalit Christian theological vision and praxis. In Dalits in India Massey articulates his understanding of the origins and development of caste. ${ }^{23}$ For Massey, caste appears to be an essential and pervading aspect of Hinduism and Indian culture as whole. But British colonialism exacerbated caste differences, and Christianity, tied as it has been to what Massey characterizes as an other-worldly medievalism, has not effectively responded to the persistence of caste in Indian society and various Indian Christian denominations. Massey envisions a truly political Dalit theology that is grounded in a new sense of Dalit identity and Christian praxis. In Toward Dalit Hermeneutics he diagrams this political theology by arguing for the necessity of Dalits asserting their own agency. ${ }^{24}$ Massey attempts to retrieve a Biblically based Dalit theology, and he begins by focusing upon the use of the word "dall," a Hebrew word that means "languid" or to be "low." "What emerges is a Dalit theology that emphasizes the Judeo-Christian themes of exodus and messianism.

The political turn in Indian Protestant consideration of Dalit identity becomes more explicit in Towards a Common Dalit Ideology, a collection of essays edited by Arvind Nirmal of the Department of Dalit Theology in the Gurukul Lutheran Theological College and Research Institute. $^{26}$ While affirming liberationist critiques of Indian society and Christianity, the most engaging essays attempt to move Dalit theology beyond simplistic Marxist understandings of political economy and culture. For example, Saral K. Chatterji questions whether conventional Marxist understandings of relationship between base and superstructure can account for the persistence of caste despite changing economic conditions. ${ }^{27}$ For Chatterji, it is the work of Gramschi, particularly in his reflections on Hegelian notions of civil society, that establishes the centrality of the superstructure of culture, a superstructure that needs to be changed if "the base" is to be transformed. But the essays in this volume do not revel in theory for, as essays by Anthony Raj and Abraham Ayrookuzhiel observe, Gandhism and the politics of the 
Indian Left have failed, leaving Dalits no other option than aggressive, albeit nonviolence, resistance. ${ }^{28}$

Protestant reflections on Dalit experience often do not engage what could conventionally be called "religiosity." Instead there is a focus upon how the Dalit experience of oppression can be conceptualized and engaged within the context of a politically committed Christian praxis. While these understandings of Dalit Christian praxis draw upon Biblical themes, Marxist and neo-Marxist analyses of society predominate in specific proposals for remedying the most oppressive parts of Dalit experience. This becomes particularly clear in the treatment of women, often called "the Dalit of the Dalit." For example, in Indigenous People: Dalits Aruna Gnanadason argues against Western understandings of development that, far from bringing liberation, have alienated and dislocated Dalits from their traditional frames of meaning. ${ }^{29}$ In this volume, however, many of the essayists lay the blame for caste firmly at the feet of Brahmanical Hinduism. ${ }^{30}$

\section{Catholics and Caste}

In comparison with Indian Protestant theology, Indian Catholic theology has not devoted as much attention to issues of specific concern to Dalits. Extending from the missionary work of Roberto De Nobili through the powerful writings of Brahmabhadhav Upadhyaya to D. S. Amalorpavadass and other post-Vatican II theologians, the primary emphasis has been inculturation. While many South Indian Catholics have resisted inculturation in the form of the Catholic ashram movement or the "Twelve Points of Adaptation" of the Latin rite mass to Indian culture, Catholic Dalits have also been vociferous in opposing what many of them understand to be accommodations to Brahman religiosity. ${ }^{31}$ In Indian Catholic discourse one rarely finds an engagement of Kabir, Ravidas, Periyar, Ambedkar and other figures, both religious and political, with whom many Dalits identify. ${ }^{32}$ Perhaps in implicit recognition of this lacuna, the Catholic Bishops Conference of India ( $\mathrm{CBCI}$ ) has become progressively more active in promoting issues of Dalit concern, particularly an expansion of the reservation system to include Dalit Christians. As David Mosse and G. Prakash Reddy have observed, caste distinctions are still very much a part of Catholic communities in South India. ${ }^{33}$ Perhaps for this reason, caste and Untouchability often receive rather conflicted treatments in Indian Catholic discourse.

The late George Soares-Prabhu, a Jesuit and professor at the Pontifical Athenaeum in Pune, was one of the most ardent critics of the inculturation movement. Writing to Bede Griffiths and the other leaders of the Catholic ashram movement, Soares-Prabhu sets his critique within the context of pervasive violence against Untouchables. Observing that he has "yet to hear a Shankaracarya or head of an ashram publicly condemn" these atrocities, SoaresPrabhu firmly states that "Brahmanical Hinduism" is thoroughly unrepentant about its complicity in the oppression of Dalits, Tribals and women. ${ }^{34}$ By adopting a rarified and Brahmanical form of Hinduism in its religious life, Catholic ashrams are aligning themselves with some of the most regressive forces within Indian society. Catholic ashrams could be of service, Soares-Prabhu suggests, if they were "to communicate to Hinduism something of the painful purification Christians have undergone because of the challenge of the reformation and the fires of humanist and Marxist criticism." 35 But as the writings of Bede Griffiths clearly demonstrate, the ashram movement seems more concerned with fostering "anti-consummerist values" among the "spoiled children of the West." "36 Instead, what the "decaying society of India" needs most is a truly Christian ashram that renounces contemplation in the service of liberating love. ${ }^{37}$ Hinduism thus needs to be redeemed, and this redemption cannot come 
from within caste-bound Brahmanical Hinduism that the ashrams embrace. Instead it is the liberating love of God, revealed in the Risen Christ, that can both heal and purify India's rigid and oppressive social system.

In his The Dharma of Jesus SoaresPrabhu envisions Dalits as part of the table fellowship of Jesus which includes the outcaste. ${ }^{38} \mathrm{He}$ recalls how Peter refused table fellowship to Gentile Christians in Antioch because of what Soares-Prabhu describes as the Jewish "caste system." Soares-Prabhu glosses Paul's reaction to Peter, he argues that it was not so much the discrimination that became the issue per se, but instead the conviction that any return to the Law and its elaborate standards of purity would "dilute" the commitment to the redemptive power of Jesus. In comparing the situation faced by the Church of Corinth to that confronting Indian Catholicism today, Soares-Prabhu argues that it is grace, not works, that allows admission to Christ's table. ${ }^{40}$ For the excluded, whether Dalit or African-American, the standard is not "cleanness," but "love."41

Soares-Prabhu's' critiques would be considered relatively radical within the immediate context of Indian Catholic discourse, although many Indian Protestant theologians would find many points of agreement. In contrast, other Indian Catholic theologians have envisioned Catholicism as aid to "Sanskritization," a term coined by the Indian sociologist T. N. Madan, to describe low caste imitation of high caste customs for the purpose of hierarchical advancement. In arguing for "Christianization as a Legitmate Alternative to Sanskritization," Augustine Kanjamala focuses upon how Dalits and Tribals have, in limited ways, succeeded in raising their status within the surrounding hierarchy by accepting Christianity. ${ }^{42}$ Kanjamala diagrams a five-stage model of "Christianization," beginning with an alternation between Christian and indigenous rituals and moving eventually toward a self-consciously Catholic Christian appropriation and reinterpretation of local customs. Within this progression Catholic Christian converts are able to distance themselves from the practices and customs that relegate them to the lowest levels of the social hierarchy. Of course, this vision is perhaps as controversial as Soares-Prabhu's liberationalist critiques, since it does imply a Christian superiority, even though Kanjamala does wish to draw attention to how Christian exclusivity has been a kind of counter-witness to the Gospel within Indian society. It is against what Indians would call "communalistic" understandings of conversion that A. Pushparajan argues that conversion actually does not reflect the work of the Church itself, since all authentic conversion is the result of God's grace. ${ }^{43}$ In affirming the patriotism of Catholic Christians and their acceptance of the constraints of living in Indian civil society, Pushparajan perhaps inadvertently reveals the deep ambivalence within Indian Catholicism to issues regarding Dalit religion, culture and assertions of agency.

\section{Conclusion}

One of the striking aspects of surveying approaches to Hinduism, Christianity and Dalit religiosity is that there is very little dialogue between anthropology and theology, although both are concerned with "history" in the conventional sense. One laudable exception, however, remains Sathianathan Clarke's . Dalits and Christianity: Subaltern Religion and Liberation Theology in India. ${ }^{4}$ Clarke focuses upon Paraiyar communities in South India and their symbols of the goddess and the drum. For Clarke there is a "christic presence as appropriated by the drum," an echo or a vibration that embodies the ceaseless character of the divine. ${ }^{45}$ By using indigenous Dalit symbols to articulate a Dalit liberationist vision Clarke creates an opening for serious consideration of ethnography as a crucial resource for 
theological reflection. Through this engagement perhaps the reified understandings of Hinduism and Christianity and their relationship to caste will finally give way to more nuanced understandings of the diversity of Dalit experience and religious sensibilities - an approach that draws its strength from a refusal to reduce and oppose Hinduism and Christianity as competing essentialized wholes.

\section{Notes}

1. Mulk Raj Anand, Untouchable (London: Penguin Books, 1940).

2. Arjun Appadurai, "Is Homo Hierarchicus," American Ethnologist 13 (1986): 745-761.

3. John Webster, "Who is a Dalit"? in Dalits in Modern India: Visions and Values, ed. S. M. Michael (New Delhi: Vistaar Publications, 1999), pp. 68-79.

4. John C. B. Webster, The Pastor to Dalits (New Delhi: ISPCK, 1995).

5. James Freeman, Untouchable: An Untouchable Life History (Stanford CA: Stanford University Press, 1979).

6. Abbé J. A. Dubois, Hindu Customs, Manners and Ceremonies, trans. Henry $\mathrm{K}$. Beauchamp (Oxford: Clarendon Press, 1906).

7. Ibid., p. 52.

8. Ibid., p. 54.

9. George Briggs, The Chamars (Delhi: D. K. Agencies, 1995).
Briggs' work was originally published in 1920.

10. Bernard Cohen, "A Chamar Family in a North Indian Village: A Structural Contingent" in Bernard Cohen, An Anthropologist Among the Historians (New Delhi: Oxford University Press, 1996), pp. 308-319.

11. Michael Moffat, An Untouchable Community in South India: Structure and Consensus (Princeton, NJ: Princeton University Press, 1979).

12. Robert Deliège, "Replication and Consensus: Untouchability, Caste and Ideology in India," Man, n.s. 27 (1992): 155-173.

13. André Beteille, The Backward Classes and the New Social Order (Delhi: Oxford University Press, 1981).

14. J. Wascom Pickett, Christian Mass Movements in India (New York, 1933); John C. B. Webster, The Dalit Christians: A History, (New Delhi: ISPCK, 1994).

15. Saurabh Dube, Untouchable Pasts: Religion, Identity and Power among a Central Indian Community, 1780-1950 (Albany NY: SUNY Press, 1998).

16. Ramdas Lamb, Rapt in the Name: The Ramnamis, Ramnam, and Untouchable Religion in Central India (New York: SUNY Press, 2002).

17. Ibid., p. 62. 
18. Ravindra S. Khare, The Untouchable As Himself (New York: Cambridge University Press, 1964)

19. Ibid., p. 79 .

20. Ibid., p. 147.

21. Rosalind O'Hanlon and Michael Washburn, "After Orientalism: Culture, Criticism and Politics in the Third World," Comparative Studies in Society and History 34, no. 1, (January 1992): 141-167.

22. Gayatri Chakravorty Spivak, "Introduction," in Selected Subaltern Studies, ed. Ranajit Guha and Gayatri Chakrovarty Spivak (New York: Oxford University Press, 1998), p. 11.

23. James Massey, Dalits in India (New Delhi: Manohar, 1995).

24. James Massey, Towards Dalit Hermeneutics (Delhi: ISPCK, 1994).

25. Ibid., p. 3.

26. Arvind P. Nirmal, ed., Towards a, Common Dalit Ideology (Madras: Gurukul Lutheran Theological College and Research Institute, n.d.)

27. Saral K. Chatterji, "Some Aspects of Dalit Theology," in Nirmal, Towards a Common Dalit Ideology, pp. 1-18

28. Anthony Raj, "Disobedience: A Legitimate Act for Dalit Liberation," in Nirmal, Towards a Common Dalit Ideology, pp. 39-51; A. M. Abraham
Ayrookuzhiel, "The Ideological Nature of Emerging Dalit Consciousness," in Nirmal, Towards a Common Dalit Ideology, pp. 81-96.

29. Aruna Gnanadason, "Dalit Women: The Dalit of the Dalit," in Indigenous People: Dalits, ed. James Massey (Delhi: Cambridge Press, 1994), pp. 168-178.

30. Ruth Manorama, "Dalit Women: The Downtrodden of the Downtrodden," in Massey,

"Indigenous People: Dalits, pp. 161-162.

31. On Dalit resistance to Catholic inculturation, see Mathew N. Schmalz, "Ad Experimentum: Theology, Anthropology and the Paradoxes of Indian Catholic Inculturation," Theology and the Social Sciences, ed. Michael Barnes (Maryknoll NY: Orbis Books, 2001), pp. 161-180.

32. For a discussion of a Catholic Dalit interpretation of Kabir, see Mathew N. Schmalz, "Images of the Body in the Life and Death of a North Indian Catholic Catechist," History of Religions 39 (November 1999): 177-201.

33. David Mosse, "South Indian Christians, Purity/Impurity and the Caste System: Death Ritual in a Tamil Roman Catholic Community," Journal of the Royal Anthropological Institute 2, no. 3 (1996): 461-483; G. Prakash Reddy, "Caste and Christianity: A Study of Shudra Caste Converts in Rural Andhra 
Pradesh," in Religion and Society in South India, ed. V. Sudarsen (Delhi: B. R. Publishing Corp., 1987), pp. 1032.

34. George Soares-Prabhu, S. J., "A Letter from George SoaresPrabhu to Vandana Mataji," in Christian Ashrams - $A$ Movement with a Future? (New Delhi: ISPCK, 1993), p. 154.

35. Ibid., p. 154.

36. Ibid., p. 154.

37. Ibid., p. 155.

38. George Soares-Prabhu, S. J., The Dharma of Jesus, ed. Francis Xavier D'Sa, S. J. (Maryknoll, NY: Orbis Books, 2003).

39. Ibid., p. 128.

40. Ibid., p. 128.

41. Ibid., p. 129.

42. Augustine Kanjumala, S.V.D., "Christianization as a Legitimate Alternative to Sanskritization," Indian Missiological Review 6 (October 1984): 307-321.

43. A. Pushparajan, "Are Christian Conversions Communalistic?" Indian Missiological Review 6 (October 1984): 265-289.

44. Sathianathan Clarke, Dalits and Christianity: Subaltern Religion and Liberation Theology in India (Delhi: Oxford University Press, 1999).
45. Ibid., p. 202.

\section{For Further Reading}

\section{General Works on Untouchability}

Robert Deliège, The Untouchables of India, trans. Nora Scott (Oxford: Berg, 2000).

Mark Juergensmeyer, Religion as a Social Vision (Berkeley: University of California Press, 1982).

Michael J. Mahar, ed. The Untouchables in Contemporary India (Tucson: University of Arizona Press, 1972).

Oliver Mendelsohn and Marika Vicziany, The Untouchables: Subordination, Poverty and the State in Modern India (Cambridge: Cambridge University Press, 1998).

Vijay Prashad, Untouchable Freedom: A Social History of a Dalit Community (New Delhi: Oxford University Press, 2000).

$\underline{\text { Untouchability and Christianity }}$

Robert Deliège, "Untouchability and Catholicism: The Case of the Paraiyars in South India," Comparative Studies of South Asia, Africa and the Middle East 18 (1998): 30-34.

Duncan B. Forrester, Caste and Christianity (London: Curzon Press, 1980).

Xavier Irudayaraj, S.J., ed., Emerging Dalit Theology (Madras: Jesuit Theological Secretariate, 1990).

M. E. Prabhakar, Towards a Dalit Theology (Delhi: ISPCK, 1988).

K. N. Sahay, Christianity and Culture Change in India (New Delhi: Inter-Media Publications, 1986). 
A Bibliographic Essay on Hindu and Christian Dalit Religiosity 65

Untouchability and Hinduism

Pauline Kolenda, "The Functional Relations of a Bhangi Cult," in Caste, Cult and Hierarchy: Essays on the Culture of India (Delhi: Folklore Institute, 1984).

David Lorenzen, Praises to a Formless God: Nirguni Texts from North India (Albany: SUNY Press, 1996).

Gyan Prakash, "Reproducing Inequality: Spirit Cults and Labor Relations in Colonial Eastern India,"
Modern Asian Studies 20 (1986): 209-230.

Catherine Schomer and W. H. McLeod, The Sant Tradition of India (Berkeley: University of California Press, 1981).

Darshan Singh, Sant Ravidas and His Times (Delhi: Kalyani Publishers, 1978). 